\title{
Silage fermentation attributes and certain rumen parameters in sheep fed two grass silages harvested at different stages of maturity
}

\author{
Abubeker Hassen", W.A. van Niekerk and F.M. Bechaz \\ Centre for Nutrition, Department of Animal and Wildlife Sciences, University of Pretoria, Pretoria 0002, South Africa
}

\begin{abstract}
The aim of this study was to compare two tropical grass species, Panicum maximum and Digitaria eriantha, in terms of silage fermentation attributes and certain rumen fermentation characteristics of silage made either at the boot or full bloom stages of growth. A lower silage $\mathrm{pH}$ was recorded for the $D$. eriantha than for the $P$. maximum silage. Neither species nor maturity stage had a significant effect on silage ammonia nitrogen, or lactic, acetic and butyric acid concentrations. For P. maximum silage total $\mathrm{N}$ was higher at full bloom than at the boot stage. $D$. eriantha had a higher total nitrogen content than $P$. maximum silage at the boot stage. Rumen $\mathrm{pH}$ was lower in sheep fed $D$. eriantha than $P$. maximum silage. In $P$. maximum fed sheep, a higher rumen $\mathrm{NH}_{3}-\mathrm{N}$ concentration was recorded when silage from the full bloom stage was fed compared to silage from the boot stage. In sheep fed $D$. eriantha silage, higher concentrations of acetic, propionic, butyric and total volatile fatty acids in the rumen were recorded from full bloom than from the boot stage. Neither species nor stage of maturity had significantly influenced the acetic : propionic acid ratio. The results suggested no significant difference between the species, but the full bloom stage showed a higher nutritive value and better preservation compared to the boot stage silage in both $D$. eriantha and $P$. maximum silage.
\end{abstract}

Keywords: Boot stage, Digitaria eriantha, full bloom stage, Panicum maximum, rumen fermentation

${ }^{\#}$ Corresponding author. E-mail: abubeker.hassen@up.ac.za

\section{Introduction}

Panicum maximum (Guinea grass) and Digitaria eriantha (Smuts finger) are high yielding subtropical perennial grasses grazed by cattle and sheep in southern Africa. Excess forage can be removed for hay or silage making. Ensiling tropical grasses such as D. eriantha and P. maximum showed sub-optimal (often poor) initial silage fermentation (Mühlbach, 2000) due to either a low dry matter (DM) content, high buffer capacities, low level of suitable lactic acid bacteria and a low water-soluble carbohydrate (WSC) content, or a combination of these factors (Mühlbach, 2000). The objective of this study was to compare silage fermentation attributes and certain rumen fermentation characteristics of $P$. maximum and $D$. eriantha silages made either at the boot or full bloom stages of growth.

\section{Materials and Methods}

Panicum maximum and D. eriantha pastures were harvested from an area of 0.4 ha at two different stages (boot and full bloom) of growth. The harvested forage for each species were separately wilted to a dry matter concentration of 30\% and ensiled with an addition of $8 \mathrm{~kg}$ sugar/ton DM in airtight plastic bags (3.1 $\mathrm{m} \times 2.75 \mathrm{~m}$ ). The silos were opened at day 120 and representative samples were analysed to determine the fermentative and nutritive value characteristics. Silage nitrogen (N) content was analyzed according to AOAC (2000).

Four rumen cannulated sheep were randomly allocated to one of the four silage diets for the rumen fermentation study. It was a 2 x 2 factorial treatment consisting of two grass species (P. maximum or $D$. eriantha) and two growth stages (boot or full bloom stage of growth) at harvest. The sheep were housed in individual metabolism cages and were fed ad libitum three times daily. The animals had free access to a 50 : 50 dicalcium phosphate/salt lick and fresh water was available.

Sampling of rumen fluid was done over four consecutive days at 09:00 and 21:00 on day 1; at 12:00 and 24:00 on day 2; at 15:00 and 03:00 on day 3; and at 18:00 and 06:00 on day 4 . The rumen pH was 
measured immediately after sampling and the rumen fluid was stored in a freezer for later analysis. These rumen fluid samples were thawed and then filtered. The supernatant was used for the determination of rumen ammonia nitrogen $\left(\mathrm{NH}_{3}-\mathrm{N}\right)$ and volatile fatty acid (VFA) concentrations after separate samples from each treatment were preserved with $4 \mathrm{~mL} 0.5 \mathrm{M}$ sulphuric acid or $2 \mathrm{~mL}$ of a $10 \%$ sodium-hydroxide solution, respectively. Volatile fatty acid and lactic acid concentrations were measured according to the methods of Payne \& McDonald (1966) and Pryce (1969), respectively.

All parameters measured in the experiments were analyzed using Proc GLM of SAS (2001). The influence of grass species and growth stage was investigated and where the $\mathrm{F}$ ratio showed significance differences $(\mathrm{P}<0.05)$, the means were tested using the Bonferroni's test according to Samuels (1989).

\section{Results and Discussion}

The silage DM content differed significantly between the grass species (Table 1). At boot stage, $P$. maximum had a higher DM content than $D$. eriantha silage, whereas at full bloom stage $P$. maximum had a lower DM concentration than D. eriantha silage. The DM concentration of the forages prior to ensiling and at feeding plays a key role in determining the silage fermentation characteristics and intake by the animal (Ingvartsen, 1992). In general, the organic matter (OM) concentration of $D$. eriantha silage was higher than that of $P$. maximum silage. At boot stage the $\mathrm{N}$ concentration of $D$. eriantha silage was higher than that of $P$. maximum, but when compared at full bloom stage the species did not differ in terms of their $\mathrm{N}$ concentrations. The $\mathrm{NH}_{3}-\mathrm{N}$ concentrations were also not significantly different between the two species. In general, $\mathrm{NH}_{3}-\mathrm{N}$ values were within an acceptable range $\left(<100 \mathrm{~g} \mathrm{NH}_{3}-\mathrm{N} / \mathrm{kg} \mathrm{N}\right)$ for well-fermented silages (Stark \& Wilkinson, 1988), and lower than values reported by Meeske et al. (1999) for D. eriantha (50.3 g $\mathrm{N} / \mathrm{kg}$ ) silage ensiled for 44 days. In general, $D$. eriantha silage had lower $\mathrm{pH}$ values than the $P$. maximum silage. However, the $\mathrm{pH}$ values for grass silage were closer or less than 5, and according to McDonald et al. (1991), for wilted silages, a stable silage can be achieved at pH values of 5 and above due to the higher

Table 1 Silage quality of Panicum maximum and Digitaria eriantha at boot and full bloom stage of growth

\begin{tabular}{|c|c|c|c|}
\hline \multirow{2}{*}{ Silage fermentation parameters } & \multirow{2}{*}{$\begin{array}{l}\text { Stage of growth } \\
\text { at harvest }\end{array}$} & \multicolumn{2}{|c|}{ Pasture species } \\
\hline & & P. maximum & D. eriantha \\
\hline \multirow[t]{2}{*}{$\mathrm{pH}$} & Boot & $4.5_{1}( \pm 0.40)$ & $4.2_{2}( \pm 0.40)$ \\
\hline & Full bloom & $4.7_{1}( \pm 0.40)$ & $4.4_{2}( \pm 0.40)$ \\
\hline \multirow[t]{2}{*}{ Dry matter (g/kg) } & Boot & $362.5_{1}^{\mathrm{a}}( \pm 2.8)$ & $299.8_{2}^{b}( \pm 2.8)$ \\
\hline & Full bloom & $350.8^{\mathrm{b}}( \pm 2.8)$ & $360.4^{\mathrm{a}}( \pm 2.8)$ \\
\hline \multirow[t]{2}{*}{ Nitrogen (g/kg DM) } & Boot & $18.6_{2}^{\mathrm{b}}( \pm 1.3)$ & $23.9_{1}( \pm 1.3)$ \\
\hline & Full bloom & $24.0^{\mathrm{a}}( \pm 1.3)$ & $22.3( \pm 1.3)$ \\
\hline \multirow[t]{2}{*}{ Ammonia-N (g/kg N) } & Boot & $38.1( \pm 4.3)$ & $46.8( \pm 4.3)$ \\
\hline & Full bloom & $49.6( \pm 4.3)$ & $36.2( \pm 4.3)$ \\
\hline \multirow[t]{2}{*}{ Lactic acid (g/kg DM) } & Boot & $16.2( \pm 3.4)$ & $13.0( \pm 3.4)$ \\
\hline & Full bloom & $12.6( \pm 3.4)$ & $24.1( \pm 3.4)$ \\
\hline \multirow[t]{2}{*}{ Acetic acid (g/kg DM) } & Boot & $7.0( \pm 2.5)$ & $2.6( \pm 2.5)$ \\
\hline & Full bloom & $13.7( \pm 2.5)$ & $9.3( \pm 2.5)$ \\
\hline \multirow[t]{2}{*}{ Butyric acid (g/kg DM) } & Boot & $0.20( \pm 0.4)$ & $0.07( \pm 0.4)$ \\
\hline & Full bloom & $0.06( \pm 0.4)$ & $0.23( \pm 0.4)$ \\
\hline
\end{tabular}

Means within columns (a,b) and rows $(1,2)$ with different super-/sub-scripts differ significantly at $\mathrm{P}<0.05$. 
osmotic pressure associated with wilting that probably inhibits clostridial growth. In contrast, Marsh (1979) reported lower $\mathrm{pH}$ values for wilted silages. Accordingly, except for $P$. maximum silage at full bloom stage, the $\mathrm{pH}$ values of the four silages were within an acceptable range as recommended by the same authors. However, the best indicator of silage quality is the acid profile of the silage (Bethard, 2006). In the present study the silage from the two grass species did not differ $(\mathrm{P}>0.05)$ in terms of lactic, acetic and butyric acid concentrations.

In general, the rumen $\mathrm{pH}$ value of sheep fed $D$. eriantha silage was lower than that of sheep fed the $P$. maximum silage (Table 2). The rumen $\mathrm{pH}$ followed a similar pattern to that of silage $\mathrm{pH}$. For all silage diets, however, the levels of rumen $\mathrm{pH}$ recorded were within the optimal $\mathrm{pH}$ recommendation ranges for high proteolytic (pH 6 to 7) and cellulolytic (pH 6.2 to 6.8) activities. The rumen ammonia, acetic acid, propionic acid and total volatile fatty acid concentrations did not differ $(\mathrm{P}>0.05)$ between the two grass species. However, sheep fed $D$. eriantha silage had a higher $(\mathrm{P}<0.05)$ rumen butyric acid concentration than $P$. maximum silage when compared at the full bloom stage. A similar pattern was recorded for silage $\mathrm{pH}$, though the difference was not statistically significant. Higher butyric acid in silage is an indicator of undesirable fermentation and/or secondary fermentation (Schroeder, 2004). The rumen $\mathrm{NH}_{3}-\mathrm{N}$ values recorded for sheep fed on both tropical grass silages were sufficient to support maximum microbial activity in the rumen. According to Satter \& Roffler (1975) values lower than 2.5 - $5 \mathrm{mg} / 100 \mathrm{~mL}$ rumen fluid may inhibit rumen activity, while Ørskov (1982) suggested a rumen $\mathrm{NH}_{3}-\mathrm{N}$ concentration of 20 - $24 \mathrm{mg}$ per $100 \mathrm{~g}$ rumen fluid for maximum fermentation rate.

Table 2 Rumen parameters of sheep fed Panicum maximum and Digitaria eriantha silage harvested at the boot and full bloom stage of growth

\begin{tabular}{|c|c|c|c|}
\hline \multirow{2}{*}{ Rumen parameters } & \multirow{2}{*}{$\begin{array}{c}\text { Stage of growth } \\
\text { at harvest }\end{array}$} & \multicolumn{2}{|c|}{ Pasture species } \\
\hline & & P. maximum & D. eriantha \\
\hline \multirow[t]{2}{*}{ Rumen pH } & Boot & $6.66_{1}( \pm 0.4)$ & $6.27_{2}( \pm 0.4)$ \\
\hline & Full bloom & $6.81_{1}( \pm 0.4)$ & $6.35_{2}( \pm 0.4)$ \\
\hline \multirow[t]{2}{*}{ Rumen $\mathrm{NH}_{3}-\mathrm{N}(\mathrm{mg} / 100 \mathrm{~mL})$} & Boot & $15.6^{\mathrm{b}}( \pm 1.5)$ & $16.4( \pm 1.5)$ \\
\hline & Full bloom & $20.0^{\mathrm{a}}( \pm 1.5)$ & $19.5( \pm 1.5)$ \\
\hline \multirow[t]{2}{*}{ Acetic acid (mmol/100 mL) } & Boot & $9.7( \pm 1.0)$ & $8.1^{\mathrm{b}}( \pm 1.0)$ \\
\hline & Full bloom & $9.6( \pm 1.0)$ & $10.4^{\mathrm{a}}( \pm 1.0)$ \\
\hline \multirow[t]{2}{*}{ Propionic acid (mmol/100 mL) } & Boot & $2.4( \pm 0.6)$ & $2.0^{\mathrm{b}}( \pm 0.6)$ \\
\hline & Full bloom & $2.4( \pm 0.6)$ & $2.5^{\mathrm{a}}( \pm 0.6)$ \\
\hline \multirow[t]{2}{*}{ Butyric acid (mmol/100 mL) } & Boot & $0.75( \pm 0.4)$ & $0.77^{\mathrm{b}}( \pm 0.4)$ \\
\hline & Full bloom & $0.68_{2}( \pm 0.4)$ & $0.98_{1}^{a}( \pm 0.4)$ \\
\hline \multirow[t]{2}{*}{ Total VFA (mmol/100 mL) } & Boot & $13.1( \pm 1.2)$ & $11.2^{\mathrm{b}}( \pm 1.2)$ \\
\hline & Full bloom & $13.0( \pm 1.2)$ & $14.2^{\mathrm{a}}( \pm 1.2)$ \\
\hline \multirow[t]{2}{*}{ Acetic : propionic acid ratio } & Boot & $4.0( \pm 0.6)$ & $4.1( \pm 0.6)$ \\
\hline & Full bloom & $4.0( \pm 0.6)$ & $4.1( \pm 0.6)$ \\
\hline
\end{tabular}

$\overline{\text { Means within columns (a,b) and rows }(1,2) \text { with different super-/sub-scripts differ significantly at } \mathrm{P}<0.05}$.

For D. eriantha silage, the DM concentration of the silage made at full bloom stage of harvest was higher than that made at boot stage (Table 1). In contrast, Van Niekerk et al. (2008) reported no difference in terms of DM\% when ensiled in a $1 \mathrm{~kg}$ mini-silo. For $\mathrm{D}$. eriantha, growth stage had no effect on the $\mathrm{N}$ concentration of the silage, while for $P$. maximum the $\mathrm{N}$ concentration of silages at full bloom stage was 
higher than for the boot stage silage. This was not expected and the reason for this is not clear, taking into consideration a decline in $\mathrm{N}$ concentration with advanced maturity (Relling et al., 2001). In general, growth stage had no significant effect on silage $\mathrm{pH}$, and $\mathrm{NH}_{3}-\mathrm{N}$, acetic, lactic and butyric acid concentrations of silage.

Growth stage had also no significant effect on the rumen $\mathrm{pH}$ of sheep fed on the two grass silages (Table 2). However, harvesting at full bloom stage resulted in a higher $\mathrm{NH}_{3}-\mathrm{N}$ concentration of sheep fed $P$. maximum silage compared to silages made from the same species at boot stage. $\mathrm{Th} \mathrm{NH}_{3}-\mathrm{N}$ concentration recorded for boot stage silage does not support maximal fermentation rate (Ørskov, 1982). In P. maximum silage, the observed higher $\mathrm{N}$ concentration recorded at full bloom stage and the corresponding higher rumen $\mathrm{NH}_{3}-\mathrm{N}$ concentration of sheep on this diet confirmed earlier results (Meissner et al., 1993; Relling et al., 2001) that showed a positive correlation between $\mathrm{N}$ intake and rumen $\mathrm{NH}_{3}-\mathrm{N}$ concentration. In D. eriantha silage, however, harvesting at full bloom stage resulted in higher rumen acetic, propionic, butyric and total volatile fatty acid concentrations than silages made at the boot stage. This is in accordance with Van Niekerk et al. (2008). Except for $D$. eriantha at boot stage, the values recorded for total VFA concentration are within the range reported for mature P. maximum pasture (Relling et al., 2001). Growth stage had no effect on the acetic acid to propionic acid ratio.

\section{Conclusions}

There were no significant differences between the important qualitative silage characteristics of $P$. maximum and $D$. eriantha silages. The higher nutritive value of the full bloom stage compared to the boot stage of $D$. eriantha silage was due to an improved VFA production in the rumen. Similarly, a higher rumen $\mathrm{NH}_{3}-\mathrm{N}$ concentration was recorded for $P$. maximum harvested at the full bloom stage than at the boot stage.

\section{References}

AOAC, 2000. Official methods of analysis (17th ed.). Association of Official Analytical Chemists, Inc., Arlington, Virginia, USA.

Bethard, G., 2006. Forage management from a nutritionist perspective. In: The Dairy Professional News letter. Vol. 2(6). Monsanto Dairy Business for Industry Professionals. (Accessed: http://www.thedairyprofessional.com/midwest/articles/issue6.htm).

Ingvartsen, K.L., 1992. A system for prediction of voluntary feed intake in growing cattle and use of feed intake to monitor performance. Ph.D. thesis, Department of Animal Science and Animal Health. The Royal Veterinary and Agricultural University, Copenhagen, Denmark.

Marsh, R., 1979. The effects of wilting on fermentation in the silo and on the nutritive value of silage. Grass For. Sci. 34, 1-10.

McDonald, P. Henderson, A.R. \& Heron, S.J.E., 1991. The Biochemistry of Silage. $2^{\text {nd }}$ ed. Chalcombe Publications, Marlow, Bucks, UK.

Meeske, R., Basson, H.M. \& Cruywagen, C.W., 1999. The effect of a lactic acid bacterial inoculant with enzymes on the fermentation dynamics, intake and digestibility of Digitaria eriantha silage. Anim. Feed Sci. Technol. 81, 237-248.

Meissner, H.H., Smuts, M., Van Niekerk, W.A. \& Acheampong-Boateng, O., 1993. Rumen ammonia concentrations and non-ammonia nitrogen passage to and apparent absorption from the small intestine of sheep ingesting subtropical, temperate and tannin containing forages. S. Afr. J. Anim. 23, 92-97.

Mühlbach, P.R.F., 2000. Additives to improve the silage making process with tropical forages. In: Silage Making in The Tropics with Particular Emphasis on Smallholders. Ed. t’Mannetje, L., Proc. FAO Electronic Conference on Tropical Silage. 1 September to 15 December 1999. FAO Plant Production and Protection Paper 161, Food and Agricultural Organization of the United Nations, Rome, Italy.

Ørskov, E.R., 1982. Protein Nutrition in Ruminants. Academic Press, New York.

Payne, M.J. \& McDonald, P., 1966. The buffering constituents of herbage and silage. J. Sci. Food Agric. 17, 264-268.

Relling, E.A., Van Niekerk, W.A., Coertze, R.J. \& Rethman, N.F.G., 2001. An evaluation of Panicum maximum cv. Gatton: 2 . The influence of stage of maturity on diet selection, intake and rumen fermentation in sheep. S. Afr. J. Anim. Sci. 31, 85-91. 
Pryce, J.D., 1969. A modification of the Barker-Summerson method for the determination of lactic acid. Analyst 94, 1151-1152.

Samuels, M.L., 1989. Statistics for Life Sciences. Collier Macmillan Publishers, London, UK.

SAS, 2001. Institute Inc., SAS/STAT User's Guide, Version 6, Fourth Edition, Volume 1, SAS Institute INC., Cary, N.C., USA. p. 943.

Satter, L.D. \& Roffler, R.E., 1975. Nitrogen requirement and utilization in dairy cattle. J. Dairy Sci. 58, 1219-1237.

Schroeder, J.W., 2004. Silage fermentation and preservation. NDSU Extension Service. In: http://www.ext.nodak.edu/extpubs/ansci/range/as1254.pdf\#search='Silage\%20fermentation\%20and \%20preservation'. North Dakota State University Fargo, North Dakota 58105.

Stark, B.A. \& Wilkinson, J.M., 1988. Silage Effluent: Problems and Solutions. Kingston, Canterbury: Chalcombe Publications, UK.

Van Niekerk, W.A., Abubeker Hassen \& Bechaz, F.M., 2008. Fermentative characteristics of Digitaria eriantha spp eriantha silage harvested at different stages of maturity. Afr. J. Range For. Sci. 25, 141-145. 